JIKAP PGSD: Jurnal Ilmiah Ilmu Kependidikan

Vol,3. No,2. Tahun 2019

e-ISSN: 2597-4440 dan p-ISSN: 2597-4424

This work is licensed under a Creative Commons Attribution

4.0 International License

\title{
Kemampuan Critical Thinking Dan Hasil Belajar Kelas IV SD Tingkir Tengah 02
}

\author{
Susilo Rudi ${ }^{1}$, Henny Dewi Koeswanti ${ }^{2}$, Sri Giarti ${ }^{3}$ \\ ${ }^{123}$ Pendidikan Guru Sekolah Dasar, Fakultas Ilmu Pendidikan, Universitas Kristen Satya Wacana \\ Email: ${ }^{1}$ 292015133student@uksw.edu \\ Email: ${ }^{2}$ Henny.koeswanti@uksw.edu \\ Email: ${ }^{3}$ sgiarty@gmail.com
}

\begin{abstract}
Abstrak. Penelitian ini bertujuan meningkatkan kemampuan berpikir kritis dan hasil belajar matematika siswa kelas IV SD Tingkir Tengah 02 Salatiga semester II tahun pelajaran 2018/2019. Berpikir kritis dan hasil belajar rendah karena guru menggunakan metode ceramah. Penulis memilih model Open Ended berbantuan media power point sebagai solusi. Prosedur penelitian meliputi perencanaan, tindakan, observasi dan refleksi. Hasil penelitian menunjukkan peningkatan dari Kondisi awal dengan 9 siswa atau $25,71 \%$ tuntas dan 29 siswa atau 74,29\% tidak tuntas. Pelaksanaan siklus I diperoleh hasil 29 siswa atau $82,86 \%$ tuntas dan 6 siswa atau $17,14 \%$ tidak tuntas. Siklus II sebagai tindak lanjut dan penyempurnaan siklus I dengan perolehan hasil mencapai ketuntasan sebesar 35 siswa atau 100\%. Hasil penelitian diperoleh simpulan penerapan pembelajaran Open Ended berbantuan media power point dapat meningkatkan kemampuan berpikir kritis dan hasil belajar matematika siswa kelas IV SD Tingkir Tengah 02 Salatiga semester II tahun pelajaran 2018/2019.
\end{abstract}

Kata Kunci: Hasil Belajar Matematika, Pembelajaran Open Ended.

Abstract. This study aims to improve critical thinking skills and mathematics learning outcomes of fourth-grade students of SD Tingkir Tengah 02 Salatiga in the second semester of the 2018/2019 academic year. Critical thinking and learning outcomes are low because the teacher uses the lecture method. The author chooses the Open-Ended model assisted by powerpoint media as a solution. Research procedures include planning, action, observation, and reflection. The results showed an increase from the initial condition with 9 students or $25.71 \%$ completed and 29 students or $74.29 \%$ not complete. The implementation of the first cycle results obtained 29 students or $82.86 \%$ completed and 6 students or $17.14 \%$ did not complete. Cycle II as a follow-up and improvement of the first cycle with the acquisition of achieving attainment of 35 students or $100 \%$. The results obtained by the conclusion of the application of Open-Ended learning assisted by powerpoint media can improve critical thinking skills and mathematics learning outcomes of fourth-grade students of SD Tingkir Tengah 02 Salatiga second semester of the 2018/2019 academic year.

Keywords: Mathematics Learning Results, Open Ended Learning. 


\section{PENDAHULUAN}

Dalam Proses kegiatan pembelajaran di sekolah dasar sering ditemukan adanya permasalahan yang berkaitan dengan kemampuan berpikir kritis dan hasil belajar. Permasalahan tersebut dapat ditemukan dalam berbagai mata pelajaran salah satunya adalah mata pelajaran matematika yang sering kali mengalami hambatan hasil belajar dalam ketercapaian berdasarkan KKM (Kriteria Ketuntasan Minimal) yang ditetapkan sekolah karena adanya kesalahan dalam proses pembelajaran yang dilaksanakan. Oleh sebab itu perlu adanya tindakan yang nyata sebagai upaya peningkatan kemampuan pemahaman materi sehingga hasil belajar dapat meningkat. Pembelajaran matematika perlu ditingkatkan ketercapaian akan hasil belajar karena merupakan salah satu mata pelajaran wajib dalam kegiatan belajar yang termuat dalam pelaksanaan kurikulum 2013. Dalam pelaksanaanya matematika dirancang supaya siswa berpikir kritis untuk menyelesaikan permasalahan yang diajukan. Menurut Suriasumantri (2009: 199) menyatakan bahwa: "Matematika adalah metode berpikir logis". Artinya matematika merupakan suatu cara atau teknik yang digunakan dalam berpikir logis. Guru harus mampu mengajari siswa berpikir logis dengan cara melatih siswa berpikir kritis (critical thingking) sehingga tujuan dari pembelajaran berpikir tingkat tinggi atau Higher Order Thingking Skills juga tercapai secara keseluruhan di semua mata pelajaran khususnya matematika. Ennis (2011: 34) berpikir kritis merupakan berpikir logis atau masuk akal yang berfokus pada pengambilan keputusan tentang yang dipercaya dan dilakukan seseorang. Matematika merupakan salah satu mata pelajaran yang sering membutuhkan 1 jawaban benar sehingga kita menjadi sulit mengajari siswa untuk berpikir kritis (critical thingking). Padahal dalam pelaksanaan kurikulum 2013 cangkupan Higher Order Thingking Skills tidak hanya berlaku pada mata pelajaran tematik namun juga pada pada mata pelajaran yang lain seperti matematika. Untuk itu guru harus memiliki model pembelajaran yang sesuai dengan permasalahan dalam kegiatan mengajar di kelas. Dimana model yang guru pilih harus menekankan pada pelaksanaan Higher Order Thingking Skills melalui berpikir kritis (critical thingking) khususnya pada pelaksanaan kegiatan pembelajaran matematika. Mengingat pentingnya muatan pelajaran Matematika di sekolah maka perlu adanya tindakan yang cepat dan tepat untuk meningkatkan kemampuan berpikir kritis (critical thingking) dan hasil belajar siswa rendah pada mata pelajaran matematika. Berdasarkan wawancara dengan guru kelas IV SDN Tingkir Tengah 02 ada suatu permasalahan yang menyebabkan hasil belajar siswa rendah. Hasil belajar siswa yang rendah disebabkan kurangnya kemampuan siswa dalam memahami soal evaluasi yang diberikan. Cara mengajar guru yang masih mengandalkan metode ceramah serta tidak menggunakan media belajar yang menarik juga berpengaruh pada kemampuan berpikir kritis dan hasil belajar siswa. Untuk itu perlu solusi guna meningkatkan cara berpikir kritis (critical thingking) pada diri siswa terutama pada mata pelajaran matematika. Kelemahan dalam berpikir kritis (critical thingking) siswa membuat pemahaman akan soal menjadi kurang dan akibatnya hasil belajar siswa rendah. Untuk mengatasi permasalahan tersebut diperlukan model pembelajaran yang dapat menjawab hambatan yang ada dalam pembelajaran matematika di kelas IV SD Tingkir Tengah 02. Untuk solusi yang cepat dan tepat dipilihlah model Open Ended guna meningkatkan kemampuan berpikir kritis (critical thingking) dan hasil belajar matematika siswa kelas IV SDN Tingkir Tengah 02. Model pembelajaran Open Ended mampu mendorong siswa untuk bekerja dalam kelompok diskusi dan presentasi sehingga melatih kemampuan berpikir kritis siswa. Dalam pelaksanaan pembelajarannya juga tidak membatasi jawaban siswa hanya satu saja namun jawaban yang beragam sehingga merangsang siswa untuk aktif dalam berdiskusi sehingga merangsang kemampuan berpikir kritis. Pelaksanaan model Open Ended juga didukung dengan penggunaan media powerpoint sehingga penyampaian materi lebih menarik siswa. Dengan diketahuinya permasalahan yang ada di kelas IV SDN Tingkir Tengah 02 maka dipilihlah model pembelajaran Open Ended dalam kegiatan pembelajaran karena mudah dilaksanakan dan tidak mengganggu proses pembelajaran sehingga kegiatan belajar siswa makin aktif, kreatif, efektif dan menyenangkan. Sebagaimana yang dikemukakan oleh Slameto (2003: 3) menyatakan bahwa belajar ialah suatu proses usaha yang dilakukan seseorang untuk memperoleh suatu perubahan tingkah laku yang 
baru secara keseluruhan, sebagai hasil pengalamannya sendiri dalam interaksi dengan lingkungannya. Mata pelajaran matematika sering kali mengalami hambatan hasil belajar dalam ketercapaian berdasarkan KKM (Kriteria Ketuntasan Minimal) yang ditetapkan sekolah karena adanya kesalahan dalam proses pembelajaran yang dilaksanakan. Berdasarkan $\mathrm{KKM} \geq 70$ yang ditentukan tidak ada separuh siswa yang tuntas hal ini terlihat tingkat ketuntasan secara klasikal hanya $25,71 \%$ dan hal ini sangat memprihatinkan sehingga perlu segera diberikan solusi guna meningkatkan kemampuan berpikir kritis dan hasil belajar. Tujuan penelitian ini adalah untuk meningkatkan kemampuan berpikir kritis dan hasil belajar matematika siswa kelas IV SDN Tingkir Tengah 02 Semester 2 Tahun Pelajaran 2018/2019. Menurut Cobb (Erman Suherman, 2003: 71) pembelajaran matematika sebagai proses pembelajaran yang melibatkan siswa secara aktif mengkonstruksi pengetahuan matematika. Menurut Shimada (Arsad HS, Dwi NS, Winanda Marito, 2013: 1) model Open Ended adalah suatu pendekatan pembelajaran yang dimulai dari mengenal atau menghadapkan siswa pada masalah terbuka. Langkah-langkah pembelajaran matematika dengan pendekatan Open Ended menurut Shimada (Vendiagrys, 2007: 12) sebagai berikut:

1. Pendekatan Open Ended dimulai dengan memberikan masalah terbuka kepada peserta didik, masalah tersebut diperkirakan mampu diselesaikan peserta didik dengan banyak cara dan mungkin juga banyak jawaban sehingga memacu potensi intelektual dan pengalaman peserta didik dalam proses menemukan pengetahuan baru.

2. Peserta didik melakukan beragam aktivitas untuk menjawab masalah yang diberikan.

3. Berikan waktu yang cukup kepada peserta didik untuk mengeksplorasi masalah.

4. Peserta didik membuat rangkuman dari proses penemuan yang dilakukannya.

5. Diskusi kelas mengenai strategi dan pemecahan dari problem serta penyimpulan dengan bimbingan guru.

Hujair AH. Sanaky (2009: 127-128) mengemukakan bahwa media power point adalah program aplikasi presentasi yang merupakan salah satu program aplikasi dibawah microsoft office program komputer dan tampilan ke layar menggunakan bantuan LCD proyektor. Ngalim Purwanto (2007: 43) berpendapat bahwa berpikir adalah satu keaktifan pribadi manusia yang mengakibatkan penemuan terarah kepada suatu tujuan. Manusia berpikir untuk menemukan pemahaman/pengertian yang dikehendakinya. Cece Wijaya (2010: 72) juga mengungkapkan gagasannya mengenai kemampuan berpikir kritis, yaitu kegiatan menganalisis ide atau gagasan ke arah yang lebih spesifik, membedakannya secara tajam, memilih,

Mengidentifikasi, mengkaji dan mengembangkannya ke arah yang lebih sempurna. Sudjana (2010: 22), mengemukakan hasil belajar sebagai kemampuan yang dimiliki siswa setelah menerima pengalaman belajar. Prinsip yang mendasari penilaian hasil belajar yaitu untuk memberi harapan bagi siswa dan guru untuk dapat meningkatkan kualitas pembelajaran. Kualitas dalam arti siswa menjadi pembelajar yang efektif dan guru menjadi motivator yang baik. Dalam kaitan itu, guru dan pembelajar dapat menjadikan informasi hasil penilaian sebagai dasar dalam menentukan langkah-langkah pemecahan masalah, sehingga mereka dapat memperbaiki dan meningkatkan belajarnya (Rasyid, 2008: 67).

\section{METODE PENELITIAN}

Jenis penelitian ini adalah penelitian tindakan kelas kolaboratif. PTK kolaboratif menurut Alwasilah (2007: 25) adalah suatu teknik pengajaran menulis dengan melibatkan sejawat untuk saling mengoreksi. Penelitian tindakan kelas ini akan dilaksanakan di SDN Tingkir Tengah 02 tahun pelajaran 2018/2019 pada mata pelajaran Matematika. Subyek penelitian dalam penelitian tindakan kelas ini adalah siswa kelas IV SDN Tingkir Tengah 02 yang berjumlah 35 siswa terdiri dari 15 siswa laki-laki dan 20 siswa perempuan. Variabel yang digunakan ada 2 yaitu variabel bebas dan variabel terikat. Variabel bebasnya adalah model pembelajaran Open Ended berbantuan media power point dan variabel terikatnya adalah kemampuan critical thinking dan hasil belajar.

Konsep pokok penelitian tindakan menurut Kemmis dan Mc Taggart (dalam Arikunto Suharsimi, 2002: 97) terdapat empat tahap rencana tindakan, meliputi: perencanaan (planning), tindakan (acting) dan pengamatan (observing), dan refleksi (reflecting). Pengumpulan data dalam penelitian tindakan kelas ini menggunakan teknik tes dan observasi. Pengumpulan data selain dengan menggunakan 
tes dan observasi juga akan dilakukan dengan dokumentasi untuk pengumpulan data. Teknik analisis data dalam penelitian tindakan kelas ini menggunakan teknik analisis data deskriptif komparatif, dimana data akan dianalisis dengan membandingkan prosentase ketuntasan hasil belajar yang dicapai oleh siswa pada pra siklus ke siklus 1 dan siklus 2. Indikator kinerja dalam penelitian tindakan kelas ini adalah peningkatan hasil belajar siswa setelah mengikuti proses pembelajaran dengan menggunakan model pembelajaran Open Ended Model pembelajaran Open Ended dikatakan berhasil apabila indikator hasil kinerja menunjukkan peningkatan hasil belajar siswa diatas KKM $\geq 70$ sebanyak $90 \%$ dari seluruh siswa.

\section{HASIL DAN PEMBAHASAN}

Subjek penelitian adalah seluruh siswa kelas IV SD Tingkir 02 yang berjumlah 35 siswa yang terdiri dari 18 siswa laki - laki dan 17 siswa perempuan. Perbandingan hasil kemampuan berpikir kritis siswa kelas IV SD Tingkir Tengah 02 dari kondisi awal, siklus I dan siklus II dengan menggunakan model Open Ended berbantuan media power point

Berikut adalah daftar kemampuan berpikir kritis yanga dijabarkan dalam bentuk tabel pada kondisi awal.

Tabel 4.1 Tingkat Kemampuan Berpikir Kritis Kelas IV SD Tingkir Tengah 02 Semester II Tahun Pelajaran 2018/2019 Pada Kondisi Awal

\begin{tabular}{|c|c|c|c|c|}
\hline No & Interval Nilai & Kategori Nilai KKM $\geq 70$ & Frekuensi & Persentase \\
\hline 1 & $20-25$ & SB & 0 & 0 \\
\hline 2 & $15-19$ & B & 7 & $20 \%$ \\
\hline 3 & $11-14$ & C & 13 & $37,14 \%$ \\
\hline 4 & $6-10$ & KB & 15 & $42,86 \%$ \\
\hline Nilai Tertinggi & 17 & - & - & - \\
\hline Nilai Terendah & 8 & - & - & - \\
\hline Rata - rata & 14,77 & - & - & - \\
\hline \multicolumn{5}{|c|}{ Jumlah } \\
\hline
\end{tabular}

Pada kondisi awal nilai kemampuan berpikir kritis memiliki rata - rata $14,77 \%$ kemudian pada siklus I adalah $18,64 \%$ dan pada siklus II adalah $22,46 \%$ sehingga dapat kita ketahui adanya peningkatan kemampuan berpikir kritis dari kondisi awal, siklus I, dan siklus II dengan penarapan model pembelajaran Open Ended berbantuan media power point.

Berikut rekapitulasi hasil belajar matematika siswa kelas IV SD Tingkir Tengah 02 Kondisi Awal.

Tabel 4.3 Rekapitulasi Nilai Matematika Siswa Kelas IV Pada Kondisi Awal

\begin{tabular}{|c|c|c|c|c|}
\hline \multirow{2}{*}{ No } & \multirow{2}{*}{ Nilai } & \multicolumn{2}{|c|}{ Sebelum Tindakan } & \multirow{2}{*}{ Keterangan } \\
\hline & & Jumlah Siswa & $(\%)$ & \\
\hline 1. & $<64$ & 15 & $42,86 \%$ & Tidak Tuntas \\
\hline 2. & $65-69$ & 11 & $31,43 \%$ & Tidak Tuntas \\
\hline 3. & $70-74$ & 2 & $5,71 \%$ & Tidak Tuntas \\
\hline 4. & $75-79$ & 4 & $11,43 \%$ & Tuntas \\
\hline 5. & $80-84$ & 3 & $8,57 \%$ & Tuntas \\
\hline \multicolumn{2}{|c|}{ Jumlah } & 35 & \multicolumn{2}{|c|}{$100,00 \%$} \\
\hline \multicolumn{2}{|c|}{ Nilai Rata - Rata } & \multicolumn{3}{|c|}{52} \\
\hline \multicolumn{2}{|c|}{ Nilai Tertinggi } & \multicolumn{3}{|c|}{80} \\
\hline \multicolumn{2}{|c|}{ Nilai Terendah } & \multicolumn{3}{|c|}{40} \\
\hline
\end{tabular}

Berikut hasil belajar siswa kelas IV SDN Tingkir Tengah 02 Salatiga sebelum dilakukan perbaikan yang digambarkan dalam diagram di bawah ini. 
Diagram Garis Nilai Kondisi Awal

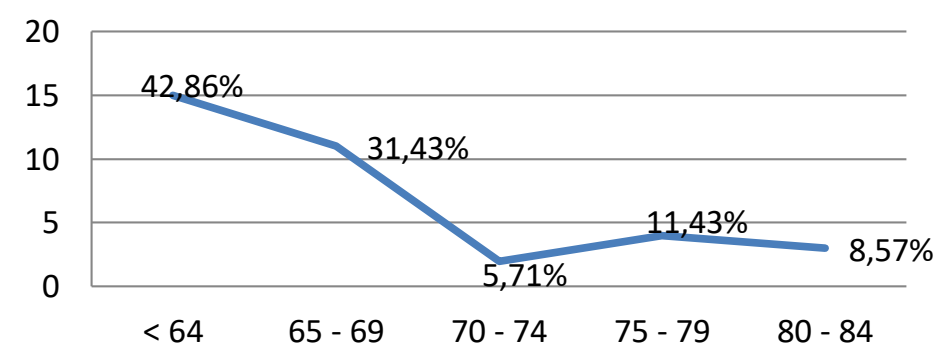

Gambar 4.2 Diagram Garis Kondisi Awal Hasil Belajar Siswa

Daftar perolehan kemampuan berpikir kritis dan hasil belajar matematika siswa kelas IV setelah penerapan model Open Ended

berbantuan media power point pada siklus I dapat diketahui sebagai berikut:

Tabel 4.6 Tingkat Kemampuan Berpikir Kritis Kelas IV SD Tingkir Tengah 02 Semester II Tahun Pelajaran 2018/2019 Pada Siklus I

\begin{tabular}{|c|c|c|c|c|}
\hline No & Interval Nilai & Kategori Nilai KKM $\geq 70$ & Frekuensi & Persentase \\
\hline 1 & $20-25$ & SB & 9 & $25,71 \%$ \\
\hline 2 & $15-19$ & B & 20 & $57,14 \%$ \\
\hline 3 & $11-14$ & C & 6 & $17,15 \%$ \\
\hline 4 & $6-10$ & KB & 0 & 0 \\
\hline Nilai Tertinggi & 24 & - & - & - \\
\hline Nilai Terendah & 13 & - & - & - \\
\hline Rata - rata & 18,64 & - & - & - \\
\hline \multicolumn{5}{|r|}{ Jumlah }
\end{tabular}

Rekapitulasi perolehan hasil belajar matematika siswa kelas IV siklus I dapat dilihat pada tabel 4.8 berikut.

Tabel 4.8 Rekapitulasi Hasil Belajar Matematika Siswa Kelas IV Siklus I

\begin{tabular}{|c|c|c|c|c|}
\hline \multirow{2}{*}{ No } & \multirow{2}{*}{ Nilai } & \multicolumn{2}{|c|}{ Siklus I } & \multirow{2}{*}{ Keterangan } \\
\hline & & Jumlah Siswa & $(\%)$ & \\
\hline 1. & $<64$ & 2 & $5,71 \%$ & Tidak Tuntas \\
\hline 2. & $65-69$ & 4 & $11,43 \%$ & Tidak Tuntas \\
\hline 3. & $70-74$ & 5 & $14,28 \%$ & Tuntas \\
\hline 4. & $75-79$ & 3 & $8,57 \%$ & Tuntas \\
\hline 5. & $80-84$ & 6 & $17,14 \%$ & Tuntas \\
\hline 6. & $85-89$ & 9 & $25,72 \%$ & Tuntas \\
\hline 7. & $90-94$ & 4 & $11,44 \%$ & Tuntas \\
\hline 8. & $95-100$ & 2 & $5,71 \%$ & Tuntas \\
\hline \multicolumn{2}{|c|}{ Jumlah } & 35 & \multicolumn{2}{|c|}{$100,00 \%$} \\
\hline \multicolumn{2}{|c|}{ Nilai rata - rata } & \multicolumn{3}{|c|}{76,8} \\
\hline \multicolumn{2}{|c|}{ Nilai tertinggi } & \multicolumn{3}{|c|}{95} \\
\hline \multicolumn{2}{|c|}{ Nilai terendah } & \multicolumn{3}{|c|}{55} \\
\hline
\end{tabular}

Ketuntasan hasil belajar matematika siswa kelas IV dapat dilihat pada tabel 4.9 berikut ini Tabel 4.9 Ketuntasan Hasil Belajar Matematika Siswa Kelas IV Pada Siklus I

\begin{tabular}{|c|c|c|c|}
\hline \multirow{2}{*}{ No } & \multirow{2}{*}{ Ketuntasan Belajar } & \multicolumn{2}{|c|}{ Jumlah Siswa } \\
\cline { 3 - 4 } & & Jumlah & $(\%)$ \\
\hline 1. & Tidak tuntas & 6 & $17,14 \%$ \\
\hline 2. & Tuntas & 29 & $82,86 \%$ \\
\hline \multicolumn{2}{r}{ Jumlah } & 26 & $100,00 \%$ \\
\hline
\end{tabular}


Kentuntasan hasil belajar matematika kelas IV SD Tingkir Tengah 02 dapat dicermati pada tabel 4.9 setelah menerapkan model Open Ended berbantuan media power point. Diketahui ketuntasan hasil belajar dari 35 siswa sebanyak 29 siswa atau $82,86 \%$ dinyantakan tuntas KKM sebesar $\geq 70$. Hal ini menunjukkan adanya peningkatan dibanding kondisi awal yang menunjukkan nilai tuntas yang diperoleh sebanyak 9 siswa atau 25,71\%. Dari hasil pelaksanaan siklus I sudah terjadi peningkatan hasil belajar dengan menerapkan model Open Ended bebantuan media power point. Namun karena indikator keberhasilan belum menunjukkan keberhasilan secara klasikal sebesar 90\% maka masih perlu dilanjutkan siklus II sebagai bentuk penyempurnaan dan peningkatan dari siklus I.

Daftar perolehan hasil belajar matematika siswa kelas IV SD Tingkir Tengah 02 penerapan model Open Ended berbatuan media power point pada siklus II dapat diketahui sebagai berikut:

Tabel 4.11 Tingkat Kemampuan Berpikir Kritis Kelas IV SD Tingkir Tengah 02 Semester II Tahun Pelajaran 2018/2019 Pada Siklus II

\begin{tabular}{|c|c|c|c|c|}
\hline No & Interval Nilai & Kategori Nilai KKM $\geq 70$ & Frekuensi & Persentase \\
\hline 1 & $20-25$ & SB & 11 & $31,43 \%$ \\
\hline 2 & $15-19$ & B & 22 & $62,86 \%$ \\
\hline 3 & $11-14$ & C & 2 & $5,71 \%$ \\
\hline 4 & $6-10$ & KB & 0 & 0 \\
\hline Nilai Tertinggi & 24 & - & - & - \\
\hline Nilai Terendah & 13 & - & - & - \\
\hline Rata - rata & 22,46 & - & - & - \\
\hline \multicolumn{5}{|r|}{ Jumlah } \\
\hline
\end{tabular}

Hasil belajar matematika setelah menerapkan model Open Ended berbantuan media power point pada siklus II sebagai dapat dilihat pada tabel 4.13 berikut. penyempurnaan dan tindak lanjut dari siklus I

Tabel 4.13 Rekapitulasi Hasil Belajar Matematika Siswa Kelas IV Siklus II

\begin{tabular}{|c|c|c|c|c|}
\hline \multirow[t]{2}{*}{ No } & \multirow[t]{2}{*}{ Nilai } & \multicolumn{2}{|c|}{ Siklus II } & \multirow[t]{2}{*}{ Keterangan } \\
\hline & & Jumlah Siswa & $(\%)$ & \\
\hline 1. & $70-74$ & 7 & $20 \%$ & Tuntas \\
\hline 2. & $75-79$ & 6 & $17,15 \%$ & Tuntas \\
\hline 3. & $80-84$ & 10 & $28,57 \%$ & Tuntas \\
\hline 4. & $85-89$ & 6 & $17,15 \%$ & Tuntas \\
\hline 5. & $90-94$ & 4 & $11,42 \%$ & Tuntas \\
\hline 6. & $95-100$ & 2 & $5,71 \%$ & Tuntas \\
\hline \multicolumn{2}{|c|}{ Jumlah } & 35 & \multicolumn{2}{|c|}{$100,00 \%$} \\
\hline \multicolumn{2}{|c|}{ Nilai rata - rata } & \multicolumn{3}{|c|}{77,68} \\
\hline \multicolumn{2}{|c|}{ Nilai tertinggi } & \multicolumn{3}{|c|}{100} \\
\hline \multicolumn{2}{|c|}{ Nilai terendah } & \multicolumn{3}{|c|}{70} \\
\hline
\end{tabular}


Keterangan dari hasil belajar siswa dapat dilihat dalam diagram lingkaran berikut ini.

\section{Diagram Lingkaran Nilai Siklus}

II

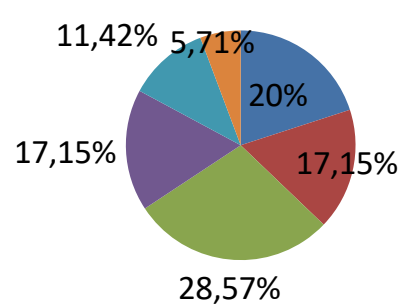

$$
\begin{array}{r}
\square 0-74 \\
\square 75-79 \\
\square \\
\square 0-84 \\
\square \\
\square 5-89 \\
\square \\
\square 0-94
\end{array}
$$

\section{Gambar 3 Diagram lingkaran hasil belajar} siswa Siklus II

Peningkatan hasil belajar dari kondisi awal, siklus I dan siklus II dapat ditunjukkan perbandingannya pada tabel 4.14 sebagai berikut.

Berikut disajikan tabel 4.14 yang memuat ketuntasan hasil belajar matematika siswa kelas IV pada siklus II.

Tabel 4.14 Ketuntasan Hasil Belajar Matematika

\begin{tabular}{cccc}
\multicolumn{3}{c}{ Siswa Kelas IV Pada Siklus II } \\
\hline \multirow{2}{*}{ No } & Ketuntasan & \multicolumn{2}{c}{ Jumlah Siswa } \\
\cline { 3 - 4 } & Belajar & Jumlah & $(\%)$ \\
\hline 1. & Tuntas & 35 & $100 \%$ \\
\hline \multicolumn{2}{c}{ Jumlah } & 35 & $100 \%$ \\
\hline
\end{tabular}

Berdasarkan tabel 4.14 dapat diketahui ketuntasan hasil belajar siswa kelas IV sudah. mengalami peningkatan dari sebelumnya siklus I yang belum menunjukkan keberhasilan secara klasikal 90\%. Setelah adanya tindakan dan penyempurnaan di siklus II, hasil belajar siswa semua mengalami ketuntasan di atas KKM sebesar $\geq 70$ yang telah ditetapkan. Dengan demikian keberhasilan secara klasikal sudah menunjukkan peningkatan lebih dari $90 \%$. Sehingga dapat disimpulkan pelaksanaan pembelajaran matematika dengan menerapkan model pembelajaran Open Ended berbantuan media power point mampu meningkatkan hasil belajar matematika siswa kelas IV SD Tingkir Tengah 02 Salatiga.

Perbandingan hasil kemampuan berpikir kritis siswa kelas IV SD Tingkir Tengah 02 dari kondisi awal, siklus I dan siklus II dengan menggunakan model Open Ended berbantuan media power point dapat kita ketahui dari tabel dan diagaram di bawah ini:

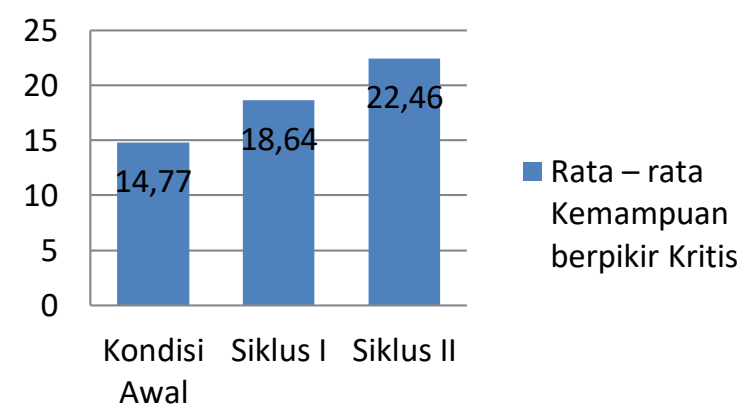

\section{Gambar 4.6 Perbandingan Kemampuan Berpikir Kritis Siswa kelas IV SD Tingkir Tengah 02}

Peningkatan hasil belajar dari kondisi awal, siklus I dan siklus II dapat ditunjukkan

\begin{tabular}{|c|c|c|c|c|c|c|c|}
\hline \multirow{2}{*}{ No } & \multirow{2}{*}{ Nilai } & \multicolumn{2}{|c|}{ Kondisi Awal } & \multicolumn{2}{|c|}{ Siklus I } & \multicolumn{2}{|c|}{ Siklus II } \\
\hline & & Jumlah Siswa & $(\%)$ & Jumlah Siswa & $(\%)$ & Jumlah Siswa & $(\%)$ \\
\hline 1 & Tidak Tuntas & 26 & $74,29 \%$ & 6 & $17,14 \%$ & 0 & 0 \\
\hline \multirow[t]{2}{*}{2} & Tuntas & 9 & $25,71 \%$ & 29 & $82,86 \%$ & 35 & $100 \%$ \\
\hline & Jumlah & & $100,00 \%$ & 35 & $100,00 \%$ & 35 & $100 \%$ \\
\hline \multicolumn{2}{|c|}{ Nilai rata -rata } & \multicolumn{2}{|l|}{52} & \multicolumn{2}{|c|}{76,80} & \multicolumn{2}{|l|}{77,68} \\
\hline \multicolumn{2}{|c|}{ Nilai Tertinggi } & \multicolumn{2}{|l|}{80} & \multicolumn{2}{|c|}{95} & \multicolumn{2}{|l|}{100} \\
\hline \multicolumn{2}{|c|}{ Nilai Terendah } & \multicolumn{2}{|l|}{40} & \multicolumn{2}{|c|}{55} & \multicolumn{2}{|l|}{70} \\
\hline
\end{tabular}
perbandingannya pada tabel 4.15 sebagai berikut.

Tabel 4.15 Rekapitulasi Ketuntasan Hasil Belajar Matematika Siswa Kelas IV Pada Kondisi Awal, siklus I, dan Siklus II

Berdasarkan tabel 4.11 dapat diketahui kondisi awal kelas IV SD Tingkir Tengah 02 sebelum melaksanakan model Open Ended berbantuan media power point diketahui dari 35 siswa sebanyak 26 siswa atau $74,29 \%$ tidak tuntas $\mathrm{KKM} \geq 70$ dan hanya 9 siswa atau $25,71 \%$ tuntas. 
Pada siklus I setelah dilaksanakan model Open Ended berbantuan media power point terjadi peningkatan hasil belajar siswa kelas IV SD Tingkir Tengah 02. Peningkatan hasil belajar dapat diketahui dari peningkatan nilai ketuntasan siswa yaitu meningkat menjadi 29 siswa atau $82,86 \%$ dan 6 siswa atau $17,14 \%$ tidak tuntas. Perolehan nilai rata - rata adalah 76,80 , nilai tertinggi adalah 95 dan nilai terendah adalah 55 .

Ketuntasan hasil belajar setelah melaksanakan siklus II sebagai tindak lanjut dan penyempurnaan dari siklus I diketahui dari 35 siswa kelas IV SD Tingkir Tengah 02 tidak ada siswa yang memperoleh nilai matematika di bawah KKM sebesar $\geq 70$ artinya 1005 tuntas. hal imi ditunjukkan dengan perolehan nilai rata - rata 77,68, nilai tertinggi 100 dan nilai terendah adalah 70 . sehingga keberhasilan secara klasikal dapat memenuhi indikator yang telah ditetapkan sebesar $90 \%$. berikut dapat dilihat perbandingan hasil belajar matematika siswa kelas IV pada kondisi awal, siklus I, dan siklus II.

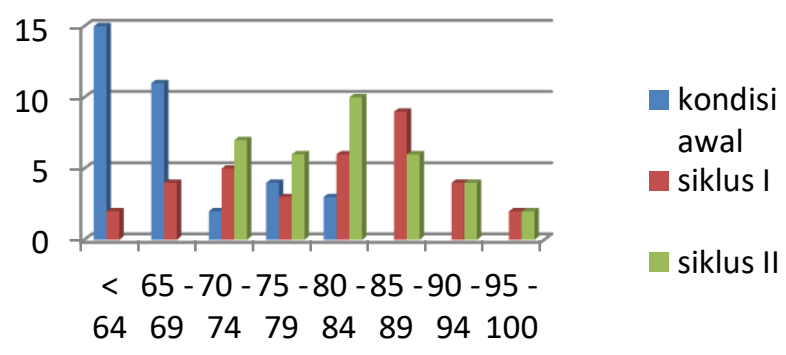

\section{Gambar 4.7 Rekapitulasi Ketuntasan Hasil Belajar Matematika Siswa Kelas IV Pada Kondisi Awal, siklus I, dan Siklus II}

Perolehan hasil belajar pada siklus II berdasarkan gambar di atas sudah menunjukkan peningkatan dibanding dengan siklus I. Hal ini menunjukkan perolehan nilai ketuntasan sebesar $100 \%$ dengan perolehan nilai berdasarkan KKM sebesar $\geq 70$ yaitu siswa yang memperoleh nilai pada rentang $70-74$ sebanyak 7 siswa, siswa yang mendapat nilai pada rentang 75-79 sebanyak 6 siswa, pada rentang 80-84 sebanyak 10 siswa, pada rentang 85-89 sebanyak 6 siswa, pada rentang 90-94 sebanyak 4 siswa, dan pada rentang 95-100 sebanyak 2 siswa. Sehingga dapat disimpulkan bahwa penerapan pembelajaran Open Ended berbantuan media power point dapat meningkatkan kemampuan berpikir kritis dan hasil belajar matematika siswa kelas IV SD Tingkir Tengah 02 pada semester II tahun pelajaran 2018/2019 hal ini ditunjukkan dengan perolehan hasil belajar siswa yang telah memenuhi KKM sebesar $\geq 70$.

Pemilihan model Open Ended sebagai solusi pemecahan masalah kemampuan berpikir kritis dan masalah hasil belajar yang rendah pada siswa kelas IV SD Tingkir Tengah 02 berdasarkan penelitian sebelumnya yang dilakukan Betty, Biliya (2014), tentang Penerapan Model Open Ended Untuk Meningkatkan Keterampilan Proses Dan Hasil Belajar Siswa Kelas V SDN 1 Repaking -
Wonosegoro - Boyolali. Dewi, Afry Pusvita. (2013) Meningkatkan Hasil Belajar Matematika Siswa Menggunakan Pendekatan Open-Ended Materi Jaring-Jaring Balok dan Kubus Kelas IV SDN Wonoketingal 1. Hasil penelitian yang dilakukan kedua peneliti menunjukkan bahwa dengan menggunakan model pembelajaran Open Ended dapat meningkatkan kemampuan berpikir kritis dan hasil belajar matematika sehingga hasil penelitian tersebut menambah keyakinan bagi penulis untuk menggunakan model Open Ended sebagai solusi meningkatkan kemampuan berpikir kritis dan hasil belajar siswa kelas IV SD Tingkir Tengah 02 Salatiga semester II tahun pelajaran 2018/2019. Berdasarkan penelitian tindakan kelas yang telah dilaksanakan pada kelas IV SD Tingkir Tengah 02 Salatiga semester II tahun pelajaran 2018/2019 melalui penerapan model pembelajaran Open Ended berbantuan media power point untuk meningkatkan kemampuan berpiki kritis dan hasil belajar siswa dapat ditunjukkan keberhasilan perolehan nilai yang meningkat melalui pembahasan di bawah ini.

Peningkatan kemampuan berpikir kritis karena keaktifan siswa dalam kegiatan pembelajaran pada saat diskusi dan presentasi dengan rata - rata kemampuan berpikir 18,64\% dengan kategori cukup dan ini mempengaruhi 
peningkatan hasil belajar yaitu diketahui dari 35 siswa kelas IV sebanyak 29 siswa atau $82,86 \%$ dinyatakan tuntas dan sisanya sebanyak 6 siswa atau $17,14 \%$ dinyatakan tidak tuntas KKM sebesar $\geq 70$. Perolehan nilai rata - rata adalah 76,8 , perolehan nilai tertinggi adalah 95 dan perolehan nilai terendah adalah 55 Karena belum memenuhi indikator ketuntasan keberhasilan secara klasikal sebesar $90 \%$ maka perlu dilanjutkan siklus II sebagai tindak lanjut dan penyempurnaan siklus I. Berdasarkan hasil refleksi dari siklus I diperoleh hasil penelitian di siklus II yakni adanya peningkatan kemampuan berpikir kritis pada siklus II yaitu dengan rata rata $22,46 \%$ dan mempengaruhi hasil belajar yang lebih meningkat dibanding siklus I. Diketahui dari 35 siswa kelas IV SD Tingkir Tengah 02 sebanyak 35 siswa tidak ada siswa yang memperoleh nilai dibawah KKM sebesar $\geq 70$ yang telah ditetapkan. Hal ini diketahui dari peroleh nilai siswa dengan perolehan nilai terendah adalah 70 dan nilai tertinggi adalah 100 kemudian nilai rata - ratanya adalah 76,80 dengan begitu ketuntasan hasil belajar sudah mencapai $100 \%$ dan memenuhi indikator keberhasilan secara klasikal yang telah ditetapkan sebesar 90\%. Sehingga ada peningkatan kemampuan berpikir kritis dan hasil belajar dari siklus I dan siklus II. Jadi dapat diketahui simpulan dari kegiatan penelitian tindakan kelas meningkatkan kemampuan berpikir kritis dan hasil belajar matematika melalui model Open Ended berbantuan media power point pada siswa kelas IV SD Tingkir Tengah 02 semester II tahun pelajaran 2018/2019 telah berhasil.

\section{SIMPULAN DAN SARAN}

Berdasarkan analisis data yang sudah diulas di bab IV berkaitan dengan penelitian tindakan kelas yang dilakukan pada siswa kelas IV SD Tingkir Tengah 02 semester 2 tahun pelajaran 2018/2019 dengan menerapkan model Open Ended berbantuan media power point dapat meningkatkan kemampuan berpikir kritis dan hasil belajar matematika kelas IV SD Tingkir Tengah 02. Peningkatan ini dapat diketahui dari hasil belajar yang diterapkan pada siklus I yakni dari jumlah 35 siswa sebanyak 29 siswa atau $82,86 \%$ tuntas dan sisanya sebanyak 6 siswa atau 17,14\% tidak tuntas KKM sebesar $\geq 70$. Kemudian dilanjutkan siklus II sebagai bentuk tindak lanjut dan penyempurnaan dari siklus I diperoleh hasil belajar yang semakin meningkat. Dapat diketahui dari 35 siswa diperoleh nilai ketuntasan sebesar 100\% sehingga memenuhi indikator keberhasilan secara klasikal sebesar $90 \%$.

Guru sekolah dasar dapat menerapkan model pembelajaran Open Ended berbantuan media power point dalam menyampaikan materi pembelajaran untuk peningkatan kemampuan berpikir kritis dan hasil belajar siswa pada mata pelajaran matematika.

\section{DAFTAR PUSTAKA}

Alwasilah, Cahedar. 2007. Pokoknya menulis.Bandung: PT.Kiblat Buku Utama.

Arikunto, Suharsimi. 2002. Prosuder Penelitian Suatu Pendekatan Praktek. Jakarta: PT. Rineka Cipta

Arsad HS, Dwi NS, Winanda Marito. 2013. Pendekatan Open Ended Problem. Diambil dari http//www.academia.edu. Diakses tanggal 20 Oktober 2014

Betty, Biliya (2014), Tentang Penerapan Model Open Ended Untuk Meningkatkan Keterampilan Proses Dan Hasil Belajar Siswa Kelas V SDN 1 Repaking Wonosegoro - Boyolali.

Dewi, Afry Pusvita. (2013) Meningkatkan Hasil Belajar Matematika Siswa Menggunakan Pendekatan Open-Ended Materi Jaring-Jaring Balok dan Kubus Kelas IV SDN Wonoketingal 1.

Ennis, R. H. (2011). The Nature of Critical Thinking : An Outline of Critical Thinking Dispositions and Abilities. University of Illinois. Diakses pada 18 Oktober 2016.

Nana, Sudjana 2010. Dasar-dasar Proses Belajar. Bandung: Sinar Baru.Suriasumantri (2010). Filsafat Ilmu: Sebuah Pengantar Populer. Jakarta: Pustaka Sinar Harapan

Ngalim Purwanto. 2007. Psikologi Pendidikan. Bandung: PT Remaja Rosdakarya.

Rasyid, Harun dan Mansur. 2008. Penilaian Hasil Belajar. Bandung: CV Wacana Prima

Sanaky, Hujair A.H. 2009. Media Pembelajaran, Yogyakarta: Safiria Insania Press.

Slameto. 2003. Belajar dan Faktor-faktor yang Mempengaruhinya. Jakarta: Rineka Cipta.

Shimada, S. (1997). The Significance of an Open-Ended Approach. In Shimada, S. 
JIKAP PGSD: Jurnal Ilmiah Ilmu Kependidikan

dan Becker, J. P. (Ed). The Open-Ended Approach . A New Proposal for Teaching Mathematics. Reston: VA NCTM.

Suherman, Erman, dkk. 2003. Strategi Pembelajaran Matematika Kontemporer. Bandung: PT Remaja Rosdakarya.

Wijaya, Cece. 2010 . Pendidikan Remidial. Bandung: Remaja Rosdakarya 